The Third Pole: Journal of Geography

Vol. 18 - 19: 123-132, 2019

DOI: https://doi.org/10.3126/ttp.v18i0.28013

Department of Geography Education,

Central Department of Education, T.U., Kathmandu, Nepal

\title{
SOCIOECONOMIC IMPACTS OF BIOGAS IN SUKLAGANDAKI MUNICIPALITY OF TANAHUN DISTRICT
}

\section{Tej Prasad Sigdel ${ }^{1}$}

\section{Abstract}

This paper examines socioeconomic impacts of biogas in the western hills of Nepal in general and the Suklagandaki Municipality of Tanahun district in particular. Biogas is considered as a sustainable renewable energy. It has positive environmental impacts on local, national and global levels. It is one of the most reliable alternative energy resources replacing fuel wood for cooking especially in rural areas of Nepal. On the basis of 40 biogas users sampled households, this paper revealed that more than 70 percent households reported that after the installation of biogas plant, there were some positive changes in their socioeconomic conditions. For example, the use of biogas energy has saved about 70 percent of the household fuel consumption especially for firewood and kerosene. About 60 percent households have reported that use of biogas as an energy sources has also saved them working loads and time and waste of biogas increased 65 percent of the total agricultural production. The use of biogas energy has also improved in their health through smoke prone diseases such as burning eyes, headache, coughing and throat ache. Biogas plant has also improved in household sanitary condition and practices, it has also reduced firewood consumption. This paper also indicates the negative impacts of biogas plant installation such as increase the number of mosquito population and losses of warmth in the house especially in winter season. The overall findings show that biogas has certainly beneficial for the socioeconomic changes in the rural areas of the study area.

Key words: Biogas installation, alternative energy, firewood, agriculture, fertilizer.

\section{Introduction}

Generally, physical or chemical resources are processed to generate energy to providelight or heat for domestic and industrial uses. Because energy can only be transformed from

1 Sigdel is a Lecturer, Central Department of Geography Education, Central Department of Education, Tribhuvan University, Kathmandu Nepal,Email: sigdelteg@gmail.com 
one form to another to do work(https://byjus...). Energy is a fundamental requirement in today's world to sustain the quality of life, ensure better living, economic production and growth, and employment (https://byjus...) encyclopedia). The country like Nepal depends on two types of energy sources: renewable and non-renewable sources. The petroleum products are to be considered non-renewal energy, while wood and cow dung are a renewable energy. Most of the households in developing countries cannot use the energy available from biomass. As a result, their dependency is increasing on petroleum products, timber and cattle dung for cooking, heating and lightening energy sources. However, biomasses also provide a reliable energy sources for rural area. Rural people can generate energy from these organic matters available locally from living organisms, such as biogas. The energy produced from biomass such as cattle dung is called biogas energy. Biogas is considered as a sustainable renewable energy source in many developing countries, including Nepal, where 83 percent of the total population resides in the rural areas (CBS, 2011). The majority of them depends on agriculture for their livelihoods where livestock farming is an integral part of the agricultural activity. There is a lot of biomass waste produced from animal, human and other substances. It can be processed to generate energy such as biogas that can be used as an alternative energy source for cooking fuel and lighting.

The term biogas is known, variously, such as swamp gas and marsh gas, however, the term popularly used Gobargas in Nepalese society. Nowadays, biogas is considered as a reliable source of energy and its demand is increasing day-by-day in both urban and rural areas. The government of Nepal has initiated appropriate technology for alternative energy to reduce on the dependency on traditional energy sources especially fuel wood. They are biogas plants, improved cooking stoves (ICS), solar energy photovoltaic system, solar dryer and micro-hydroelectricity (Pradhan \& Pradhan, 2006). It is mainly due to connecting the priceless waste to produce biogas energy which not only save firewood and kerosene based energy sources, but also have a positive impact on human health and agriculture sectors.

Biogas is a gaseous matter produced from the organic wastes such as animal dung, human excreta and plant residues by the action of bacteria in anaerobic condition i.e. in absence of oxygen. Almost all organic materials can be used for the biogas generation which requires 26 to 35 degrees temperature to produce gas. However, the high contents of wood, straw and fibers (lignin) are not used to the fermentation of biogas. The biogas has composed by a mixture of different gases, in which methane as covered the largest percentages (60-70\%) as compared to other gases. It is followed by the carbon dioxide $(30-40 \%)$ and other gases. It is about 20 percent lighter than air (Sidwal, 2007). Biogas is considered as a colourless and odorless gas that burns with a clear blue flame similar to 
that of LPG gas (BPS, 2008). Biogas can be used for multiple purposes, such as cooking, heating, and lightening and electricity generation (Sidwal, 2007).Therefore, the use of biogas is becoming more popular day-by-day. It is mainly due to biogas is an efficient, clean, hygienic and renewable source of energy for cooking and other domestic uses. Efficiency of biogas stove is better than firewood or dry dung cake (Dhital, 2009).

The demand for energy consumption has been growing in modern society at local, national and global levels. In case of Nepal, overconsumption of fossil fuel and firewood has depleted forest resource and a lot of money is spent on the imports of kerosene or petroleum fuel. Other source of energy like solar energy photovoltaic system, solar dryer, solar, wind, water power have not properly utilized in rural areas. As a result, firewood has become a main source of fuel where more than 70 percent households depend on this energy source (CBS, 2011). The over exploitation of forest has increased natural disaster such as flood, landslide, soil erosion, and Ozone layer depletion. Therefore, the problem of deforestation is increasing every day. It can be argued that the biogas plant installation has reduced the demand of petroleum product which save the large amount of foreign exchange. The waste of biogas can be used as more productive compost to produce better agricultural crops.

Various studies show that the installation of biogas plant has multifaceted benefits that can be earned by rural people. As a result, the demand for biogas is increasing dayby-day as it is quick and easy to cook, does not affect human health, and enhances agricultural production, keeps environment clean and save both time and money as well as livelihoods (Angdembey, 2012; Amgai, 2012; Gautam 2012; Karki et.al, 2009). Their findings revealed that the use of biogas has brought the significant improvement in the quality of life of the family members and reduction on the work of women. People also have benefited variously, like as waste reduction, reduction of soil and groundwater pollution, contribution to energy and environmental targets of EU, reduction of GHG emissions and diminishing of global warming etc. (Gautam, 2012).So, biogas technology has been popular in rural area. Biogas produces not only biogas but also high valued bio-fertilizer for farming. By the use of biogas farmers can meet the ever increasing energy demands and by the use of bio slurry they can minimize the use of chemical fertilizers (Karki et al., 2009).

The installation of biogas plant in Nepal was started from 1992. The government of Nepal has made the provision of subsidy to encourage the installation of biogas plant in rural areas which ultimately leads to the environmental protection of overall country due to lessening the dependence on forest for firewood (BSP, 2008). The installation of biogas plant in the Suklagandaki Municipality has recently developed and it has very short 
history. But it is very popular in the rural societies due to change their socioeconomic conditions. In this context, this paper reveals the unrivalled question how installation of biogas plants impact on the socioeconomic conditions of the households in the Suklagandaki Municipality of Tanahun District, western hills of Nepal.

\section{Methods and Materials}

The purpose of this paper is to find out the impact of biogas on socioeconomic conditions of people. For this purpose, this paper used both primary and secondary data sources. Primary data were collected from field observation, personal interview and focus group discussion. Out of 131 biogas installer households about 40 households were randomly selected for detail study from Suklagandaki Municipality. It lies in the western side of Tanahun district. Secondary data were collected from various sources such as VDC and DDC records, published journals, research reports, books and magazines and internet.

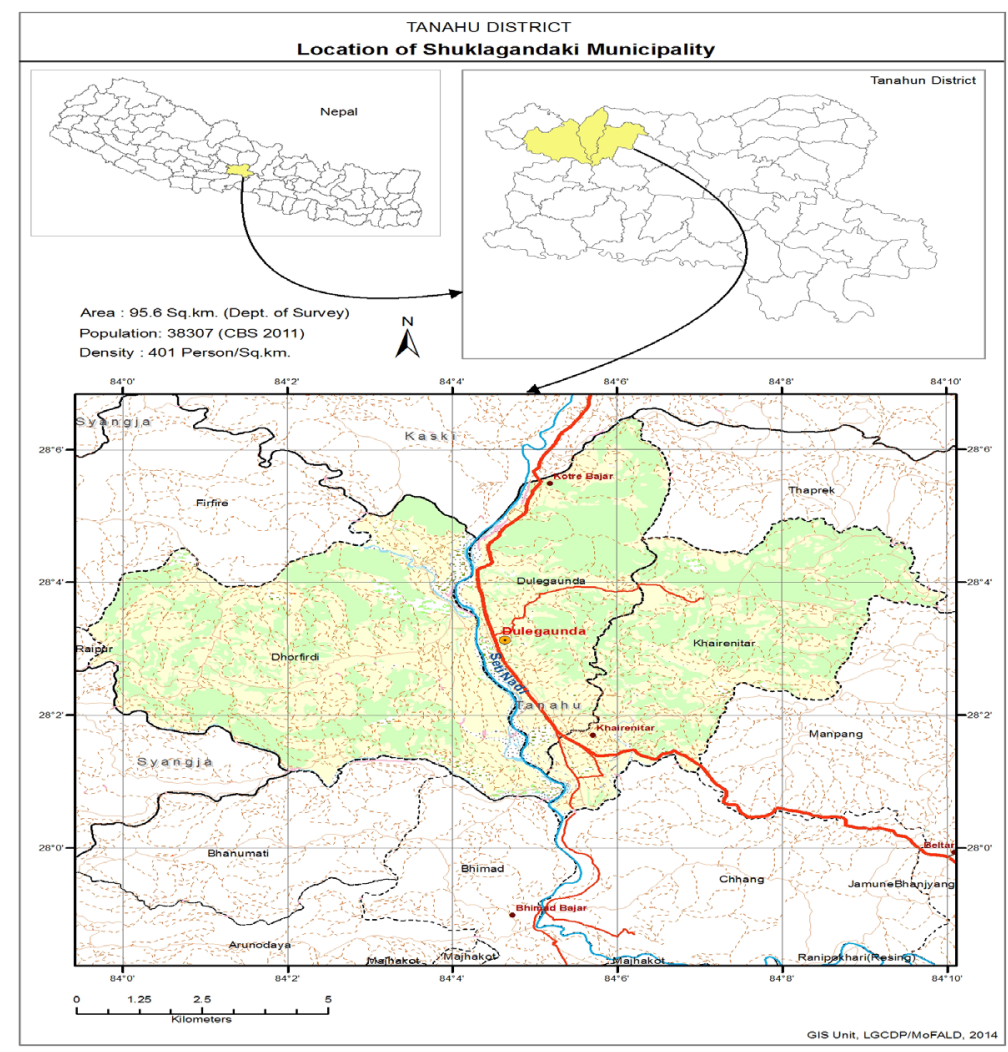

Figure 1: Location map 


\section{Result and Discussion}

\section{Historical development of biogas plant}

Biogas is known as gobar gas and it is popularly used in rural area of Nepal. The historical growth and development of biogas plant in Nepal has only a recent phenomenon. The effort of St. Xavier school of Godavari had considered as the first biogas plant in Nepal and it is used for cooking since the year of 1955 (Amgai, 2012). The Government of Nepal had also initiated various alternative energy companies, such as Gobar Gas Company (GGC), Timber Corporation Nepal (TCN), and Alternative Energy Promotion Center (AEPC). The Biogas support Programme (BSP) has established to promote the biogas plant in Nepal in July 1992. Similarly, the Non-Governmental Organization, such as United Missions to Nepal, Netherlands Development Organization, Kredutabstakt Fur Wiederaugbau of Germany have been funding to the installation of biogas. Now, at the ends 2014 A.D, 2, 80,000 plants have been installed covering 70 districts of the country (Rai, 2015). In the context of Tanahun district, biogas plant was started only from 2054 B.S and nowadays, about 1493 households installed biogas plants in the district (DDC, 2068). However, the installation of biogas plant in the Suklagandaki Municipality has recently developed and it has very short history where about 131 households have installed biogas plant.

\section{Socioeconomic impact of biogas}

This paper identified that biogas is a major source of energy in the Suklagandaki Municipality. Most of the households reported that the installation of biogas has both positive and negative impacts on their socioeconomic conditions. These impacts can be summarized as follows: social impacts, reducing the consumption of kerosene and LPG uses, decreasing working loads of women and children, reducing the dependency on firewood based energy, increasing to the conservation of local environment, and increasing agricultural productivity. They also reported that biogas installation saved time to involve in social works, income generation activities, easy to cooking food, saving money and reduction of health risks. These impacts can be discussed as follows:

Social impacts of biogas are related to the daily life of the people of society. Especially, it is related to social prestige, children's education, and women's health, reducing workload and saving time. Nepalese rural society is dependent on agriculture. People of rural area spent many time to collect firewood and Cow dung for cooking purpose. So that to save the time and to reduce the workload of rural area's people, biogas plant is very useful. The installation of biogas has brought some changes on social condition of the people of study area. Some of them have been mention here: 
Time saving. The study reveals that after installation of biogas plant how households save their times and working loads. Most of the households reported that biogas installation has saved both time and working loads for the collection of fire woods, cooking and washing utensils. Family members especially women and children can use this time in other activities like farming, petty trading, reading and so on. Table 1 shows that the perception of women regarding to the benefits of biogas plant installation in their way of living.

Table 1: Reduction in workload and time saving

\begin{tabular}{|c|c|c|c|c|c|}
\hline \multirow{2}{*}{$\begin{array}{l}\text { Category of } \\
\text { work }\end{array}$} & \multicolumn{2}{|c|}{ Time spent (Hours) } & \multirow{2}{*}{$\begin{array}{l}\text { Time Saving } \\
\text { (Average in } \\
\text { Hours) }\end{array}$} & \multirow{2}{*}{ Household } & \multirow[b]{2}{*}{ Percent } \\
\hline & $\begin{array}{c}\text { Before } \\
\text { Installation }\end{array}$ & After Installation & & & \\
\hline $\begin{array}{l}\text { Firewood } \\
\text { Collection }\end{array}$ & 3 & 1 & 2 & 34 & 85 \\
\hline Cooking & 3 & 1.5 & 1.5 & 29 & 72 \\
\hline Washing Utensils & 1 & 0.5 & 0.5 & 21 & 52.5 \\
\hline ww & 7 & 3 & 4 & & \\
\hline
\end{tabular}

Source: Field Survey, 2014

Table 1 reveals that, before the biogas installation, 85 percent households have spent 3 hours per day for firewood collection, 72.5 percent households have spent 3 hours per day for cooking and 52.5 percent households have spent one hour per day for washing utensils, whereas after the biogas installation households have spent only 1 hour per day for firewood collection, 1.5 hours per days for cooking and 0.5 hours per day for washing utensils. On this basis of figure it can be argued that most of the respondents devoted about 7 hour time to collect firewood, to cook food and to wash utensils before the installation of biogas. Nowadays, 3 hours per day time is sufficient to complete these works. They have reported that they are utilizing the saving time in diversify economic activities especially commercial vegetable farming.

Reduction in health problems. The biogas plant also has positive impact on the personal health of the family member in general women in particular. Most of the households reported that they were suffering from various smoke induced diseases, such as eye burning, respiratory, headache, and cough related problems. However, after the installation of biogas these problems reduced due to clean and smokeless environment in the cooking stove. Table 2 shows the number and percentage of households suffering from different smoke related health problems. 
Tej Prasad Sigdel / Socioeconomic Impacts of Biogas in Suklagandaki Municipality ...

|| $129 \|$

Table 2: The number of households suffering from smoke related health problems

\begin{tabular}{l|c|c}
\hline Health Problem & Household & Percentage \\
\hline Eye burning & 16 & 40 \\
Respiratory & 12 & 30 \\
Headache & 8 & 20 \\
Coughing & 3 & 7.5 \\
Not stated & 1 & 2.5 \\
\hline Total & 40 & 100 \\
\hline
\end{tabular}

Source: Field Survey, 2014

Table 2 shows the households suffering from smoke related health problems. The figure indicates that the majority of households (40\%) were suffering eye burning problems. It is followed by respiratory problem in the second (30\%), headache (20\%) and least by cough $(7.5 \%)$. The synthesis of the respondent views reveals that the use of smokeless biogas as a source of fuel helps to keep houses, kitchens and indoor environment free from air pollution. They claimed that the installation of biogas has reduced the health related problems and it has saved the cost of treatment.

\section{Economic impact of biogas}

The use of biogas has some economic impact. By the use of biogas it is saving the cost of cooking fuel. Biogas produces less smoke which helps to decrease illness so that it saves the treatment cost. Similarly it is saves time which can be used to extra income generating activities. Biogas helps to reduce the use of chemical fertilizer which helps to saves money. Biogas has multiple uses as it can be used for cooking, heating, lightening and electricity generation simultaneously so that biogas is equally beneficial for economic aspects. The installation of biogas has brought changes on economic condition of the people of study area. Some economic impacts of the biogas on the study area are present here:

Saving in fuel consumption. The use of traditional hearth (chulho) for cooking is still popular in the rural area of Nepal. This paper reveals that most of the households were using firewood, electricity and kerosene as a sources of household energy especially for cooking, lightening and heating. They consumed about $360 \mathrm{~kg}$ (12 Bhari) firewood, 8 liters kerosene, and18 unit electricity for energy (Table 3). Nowadays, the amount of firewood, kerosene and electricity has declined in a considerable rates, such as $210 \mathrm{~kg}$, 5 liters and 10 units respectively. The figure indicates that biogas has become a reliable alternative energy source in the study area. It has supported to substitute traditional fireplace or hearth. The reduction of energy consumption from firewood, kerosene and 
electricity has reduced the households' expenses in fuel and it has ultimately supported to substitute petroleum.

Table 3: Comparative status of fuel consumption before and after biogas installation

\begin{tabular}{l|c|c|c}
\hline \multirow{2}{*}{ Fuel types } & \multicolumn{2}{|c|}{ Fuel Consumption (per month) } & \multirow{2}{*}{ Saving } \\
\cline { 2 - 3 } & Before & After & 7 Bhari \\
\hline Firewood (Bhari) & 12 Bhari & 5 Bhari & $51 \mathrm{t}$ \\
Kerosene (Liter) & $81 \mathrm{t}$ & $31 \mathrm{t}$ & $10 \mathrm{unit}$ \\
Electricity (Unit) & 18 unit & $8 \mathrm{unit}$ & - \\
LP gas (Cylinder) & - & - & \\
\hline
\end{tabular}

Source: Field Survey, 2014

Note: 1 Bhari $=30 \mathrm{~kg}$.

Impact on agriculture production. The key person reported that the installation of biogas has also improved the production of agricultural crops. According to them, slurry of biogas has produced more productive manure than traditional compost. The use of such type of manure helps to increase soil fertility for growing agricultural crops. Most of the households increased their farm products after the use of slurry. Table 4 shows the households responses for the benefit of the use of slurry in agricultural production.

Table 4: Households responses for the benefit of the use of slurry

\begin{tabular}{l|c|c}
\hline Production & Respondent & Percentage \\
\hline Increase & 32 & 80 \\
Decrease & 2 & 5 \\
The same & 6 & 15 \\
\hline Total & 40 & 100 \\
\hline
\end{tabular}

Sources: Field Survey, 2014

After the installation of biogas respondents are saving time 4 hours per day and they utilizing the saved time in different economic activities. Biogas helps to reduce the energy consumption from firewood, kerosene and electricity etc. which saves the cost of fuel. Similarly, Smokeless biogas helps to keep house, kitchen and indoor environment free from air pollution which helps to reduce to health problems. From the agricultural point of view, the use of slurry as the bio-fertilizer was found beneficial to increase agricultural production. So, biogas was found socially and economically beneficial in the study area. Beside the positive impacts of biogas, there are some negative impacts too. It is risky, need high installation cost, Smell occurs headache, trained human resource 
Tej Prasad Sigdel / Socioeconomic Impacts of Biogas in Suklagandaki Municipality ...

cannot be found easily for maintenance and its increases prevalence of mosquito and loss of warmth in house in winter.

\section{Conclusion}

Biogas is being popular in the rural area of Nepal. The development and implementation of biogas in Suklagandaki Municipality is short history. Biogas has socially, economically, environmentally etc. beneficial for the people of rural area. The installation of biogas has brought some changes on socioeconomic conditions of the people of the study area. After installation of biogas 4 hours per day family time has been saved, reduced smoke related health problems especially, eye problems, headache, coughing and throat ache etc. Biogas is economically beneficial too. The main economic impact or benefit of biogas has saved considerable amount of money. Biogas has reduced the consumption of firewood, kerosene and electricity. It has reduced upto 70 percent of expense on household fuel especially of firewood and 40 percent electricity consumption. The elimination of indoor air pollution has resulted in improvement in health, sanitation condition and practices. Similarly, bio fertilizer has increased up to 70 percent of agricultural production. Biogas plant has positive as well as negative impacts. The positive impacts are: it is easy in cooking food, people feel prestigious, saves time and money and reduces of health risk. It is significant in house environment especially in health and hygiene. The people especially, housewives have benefited well. They have got more time to involve in social works, income generation activities and others. The negative impacts are, it is risky, trained human resource cannot be found easily to maintenance and increased prevalence of mosquito. In spite of few negative impacts, biogas has several benefits environmentally, socially, economically, agriculturally etc. so that the government has encouraged the people of rural area to install biogas plant.

\section{References}

Alternative Energy Promotion Center. (2009). An introduction to alternative energy technology in Nepal.

Amgai, K.P. (2012). Socio-economic impacts of biogas on Padampur VDC in Chitwan, Nepal. The Third pole, Journal of Geography, 11-12, pp 16-20.

Biogas Support Programme. (2008). Biogas support programme annual profile. Kathmandu, Nepal.

CBS. (2011). National population census report- 2011. Kathmandu: CBS.

Dhital, D. N. (2009). Socio-economic impacts of biogas. Unpublished Master Degree Thesis, Central Department of Economic, T.U Kirtipur. 
District Development Committee. (2068). District profile of Tanahun.

Gautam, D. R. (2012). Utilization and benefits of biogas in the settlements along the Siddhartha highway in Syangja district, Nepal. Kathmandu: The Third Pole, Journal of Geography, 11-12, pp 6-11, Department of Geography Education, Tribhuvan University.

Karki, K. B. \& B. Gurung. (2000). Evaluation of biogas slurry extension program. Katmandu: Alternative Energy Promotion Center.

Ministry of Science and Technology. (2011). Biogas users survey 20010/2011. Kathmandu: Alternative Energy Promotion Center.

NEW ERA. (1999). Survey of users of biogas plants in Nepal. Kathmandu: Biogas Support Programme, Nepal.

Angdembey, P. K. (2012). Prospects of biogas in socioeconomic and environmental benefits to rural community of Nepal, Unpublished Master's Thesis. Rural Development Department, Mahendra Ratna Multiple Campus, Ilam.

Rai, S. (2015) Biogas Support Programme Annual Report 2014/ 2015, Kathmandu: Biogas Support Programme

Sidwal, B. B. (2007). A review of the biogas programme in Nepal. Kathmandu: Alternative Energy Promotion Center, Nepal.

https://byjus.com/physics/energy/

https://encyclopaedia.com/Alternative energy/ 